\title{
APPLICATION OF SONOELASTOGRAPHY IN REDUCING THE INVASIVE INVESTIGATIONS TO DIAGNOSE BREAST MALIGNANCY
}

\author{
Monojit Chakrabarti1 ${ }^{1}$ Md. Abdur Rahaman², Swadha Priyo Basu ${ }^{3}$ \\ ${ }^{1}$ Assistant Professor, Department of Radiology, Malda Medical College \& Hospital, West Bengal. \\ ${ }^{2}$ RMO cum Clinical Tutor, Department of Radiology, Malda Medical College \& Hospital, West Bengal. \\ 3 Professor and HOD, Department of Radiology, Malda Medical College \& Hospital, West Bengal.
}

ABSTRACT
BACKGROUND
Breast cancer is the most common malignant lesions in female population and which is diagnosed reliably with the help of
imaging along tissue biopsy. In recent times, sonoelastography can minimize the chance of invasive investigation to diagnose breast
cancer.

\section{METHODOLOGY}

The study was conducted for the period from April 2014 to September 2015 over 200 patients, of which 50 had got breast lesions; 50 patients were evaluated by HRUS, Colour Doppler (CD), Sonoelastography (SE) and FNAC. The findings of SE were correlated with FNAC results.

\section{RESULTS}

Non-Malignant Cystic lesions were represented by Blue-Green-Red mosaic pattern on SE. SE Score IV and V are indicative of malignancy almost all the cases. The Sensitivity and Specificity of Sonoelastography of our study in predicting breast malignancy are respectively $87.5 \%$ and $92.85 \%$.

\section{CONCLUSION}

Elastography could save thousands of women from the waiting, cost, discomfort and anxiety of a biopsy.

\section{KEYWORDS}

High Resolution Ultrasonography (HRUS), Colour Doppler (CD), Sonoelastography (SE), FNAC, Breast Malignancy, Space Occupying Lesions (SOL).

HOW TO CITE THIS ARTICLE: Chakrabarti M, Md. Abdur Rahaman, Basu SP. Application of sonoelastography in reducing the invasive investigations to diagnose breast malignancy. J. Evolution Med. Dent. Sci. 2016;5(10):399-401,

DOI: $10.14260 /$ jemds/2016/91

\section{INTRODUCTION}

Breast cancer is the most common diagnosed malignancy in women worldwide $(22 \%)$ and in India it accounts $18.5 \%$ of total female malignancy. ${ }^{1}$ Increasing trend in incidence is reported from various registries of national cancer registry project and now India is a country with largest estimated number of breast cancer deaths over worldwide.2,3 The available investigations to characterize the breast lesion into benign and malignant are mammography, Ultrasonography, Colour Doppler flow, USG elastography, FNAC, etc. USG characterization of breast lesions using BIRADS-US criteria to be highly accurate. ${ }^{4}$ Although, it may be impossible to distinguish all benign from all malignant solid breast nodules using USG criteria. USG elastography seems to be quite promising. 5 The recent introduction of Sonoelastography (SE) has increased the specificity of USG and enabled earlier diagnosis of breast cancer. 6

Financial or Other, Competing Interest: None.

Submission 16-12-2015, Peer Review 17-12-2015,

Acceptance 21-01-2016, Published 02-02-2016.

Corresponding Author:

Dr. Md. Abdur Rahaman,

RMO, Department of Radiology,

Malda Medical College \& Hospital,

English Bazar, Malda-732101,

West Bengal, India.

E-mail:drrahaman@yahoo.com

DOI: $10.14260 /$ jemds/2016/91
SE detect benign lesion as having similar elasticity similar to normal tissue of the surroundings while malignant lesion having harder elasticity than adjacent tissue. ${ }^{7}$ Benign lesions appear similar to the adjacent tissue and have a smaller diameter than on B-mode USG images. ${ }^{8}$ Malignant tumors have reduced elasticity and also display larger dimensions on elastography due to accompanying desmoplastic reaction. ${ }^{9}$ The purpose of this study was to evaluate the diagnostic utility of SE in differentiating benign from malignant breast lesions in peripheral part of West Bengal.

\section{METHODOLOGY}

This was an observational type study designed prospectively, which was conducted in Malda Town of West Bengal for the period from August 2015 to December 2015. We have selected only 50 patients by simple random sampling aged above 20 years from the 200 female patients having breast SOL and those were referred by the clinician for ultrasonographic examination of breast. These 50 patient's breast SOL were studied both radiological and pathological after explaining about the purpose of this study and taking consent from each of them. We have studied breast lesions by high frequency linear broad-band transducer (6-12 MHz) of standard machine having Colour Doppler (CD). Sonoelastography (SE) with the same equipment, employing dedicated software with an algorithm that in a very short time processes the radiofrequency impulses coming from the lesion and displays 
in real time and in colour scale the degree of tissue strain in the region of interest.

\section{Sonoelastographic Method}

After HRUS detection of the lesion of interest, the patient remains in the same position and given equal pressure on a wide area of skin surface by probe minimizing the lateral movement of it. Then sonoelastographic examination was done in real time with the B-mode US image of the lesion on the left side and the same image with colour coded elasticity features superimposed on the right side. The image of SE exam usually obtained by applying a light constant pressure with the probe in contact with the skin perpendicular to the chest wall. Findings are graded as per UENO score. ${ }^{10}$

All the 50 patients underwent High Resolution Ultrasonography (HRUS), Colour Doppler (CD), Sonoelastography (SE) and FNAC. The findings were tabulated and processed in Microsoft Excel 2013 software and were analysed manually.

\section{RESULTS}

In our study, we found $80 \%$ of breast lesions are of benign in nature and $20 \%$ are of malignant.

Among 50 patients, 7 had shown lesions having welldefined, anechoic cystic lesions without any definite solid component on HRUS, CD. No colour flow or spectral pattern were depicted on SE. They show mosaic Blue-Green-Red pattern. On FNAC, these are all constant with benign cystic lesions having serous fluid.
Another 7 patients having hypoechoic lesions with irregular tracts (finger-like projections) and subcutaneous edema on HRUS shows increased flow with PSV $<40 \mathrm{~cm} / \mathrm{s}$ on CD. Sonoelastographic findings (Score II) of these lesions show mixed pattern consistent with benign lesion. They are proved abscess and malignant lesion respectably 6 and 1 in number by FNAC.

About 14 patients show multiple cystic areas interspersed with increased fibrous tissue, which on CD no significant colour flow and they are similar to normal breast tissue on sonoelastography, which having predominant green colour (Score I) pattern consistent with benign breast lesions. In FNAC, these lesions are diagnosed as fibroadenosis.

Another 14 patients having well-defined hypoechoic SOLs with posterior enhancement noted on HRUS. CD show minimal colour flow with PSV $<40 \mathrm{~cm} / \mathrm{sec}$. SE findings are Green-Blue mosaic (Score II) and central blue- peripheral green (Score III). On FNAC twelve cases found to be fibroadenoma and another two found to be malignant. Eight patients show irregular hypoechoic lesions on HRUS, on CD 7 patients show PSV $>40 \mathrm{~cm} / \mathrm{sec}$ and only 1 patient shows PSV $<40 \mathrm{~cm} / \mathrm{sec}$. On SE these lesion appeared as mostly blue (Score IV) in central area and one patient shows blue in centre, periphery and in surroundings (Score V). On FNAC out of 7 patients having Score IV, 6 patients were diagnosed as malignant and remaining one was fibroadenoma. One patient having Score $\mathrm{V}$ was proved to be malignant lesion.

\begin{tabular}{|c|c|c|c|c|c|}
\hline \multirow{2}{*}{ USG } & \multirow{2}{*}{$\begin{array}{c}\text { No } \\
.\end{array}$} & \multirow{2}{*}{ Colour Doppler } & \multicolumn{2}{|c|}{ Sonoelastography } & \multirow{2}{*}{ FNAC Character } \\
\hline & & & Character & Frequency & \\
\hline Cyst & 7 & No Colour flow & BGR & 7 & $\begin{array}{l}\text { Non-Malignant } \\
\text { (Cyst) }\end{array}$ \\
\hline \multirow{3}{*}{$\begin{array}{l}\text { Hypoechoic lesion with tracts and } \\
\text { overlying Subcutaneous Edema }\end{array}$} & \multirow{3}{*}{7} & \multirow{3}{*}{$\begin{array}{l}\text { Increased flow and } \\
\text { PSV }<40 \mathrm{~cm} / \mathrm{sec}\end{array}$} & $\begin{array}{l}\text { Score II } \\
\text { (Blue- Green } \\
\text { Mosaic) }\end{array}$ & 6 & $\begin{array}{l}\text { Non-Malignant } \\
\text { (Abscess) }\end{array}$ \\
\hline & & & \multirow{2}{*}{$\begin{array}{l}\text { Score III (Central- } \\
\text { Blue, Peripheral- } \\
\text { Green) }\end{array}$} & 1 & $\begin{array}{c}\text { Non-Malignant } \\
\text { (Abscess) }\end{array}$ \\
\hline & & & & 1 & Malignant Tumor \\
\hline $\begin{array}{c}\text { Solid }<\text { Cystic, Areas with Increased } \\
\text { Fibrous tissue }\end{array}$ & 14 & $\begin{array}{l}\text { Absent/Minimal } \\
\text { Flow and PSV } \\
<10 \mathrm{~cm} / \mathrm{sec}\end{array}$ & $\begin{array}{l}\text { Score I } \\
\text { (Green) }\end{array}$ & 14 & $\begin{array}{l}\text { Non-Malignant } \\
\text { (Fibroadenosis) }\end{array}$ \\
\hline \multirow{3}{*}{$\begin{array}{c}\text { Hypoechoic well-defined lesion with or } \\
\text { without lobulation and with or without } \\
\text { posterior enhancement, Transverse } \\
\text { Diameter > AP Diameter }\end{array}$} & \multirow{3}{*}{14} & \multirow{3}{*}{$\begin{array}{l}\text { Minimal flow and } \\
\text { PSV }<40 \mathrm{~cm} / \mathrm{sec}\end{array}$} & $\begin{array}{c}\text { Score II } \\
\text { (Blue- Green } \\
\text { Mosaic) }\end{array}$ & 11 & $\begin{array}{l}\text { Non-Malignant } \\
\text { (Fibroadenoma) }\end{array}$ \\
\hline & & & $\begin{array}{c}\text { Score III } \\
\text { (Central-Blue, } \\
\text { Peripheral-Green) }\end{array}$ & 1 & $\begin{array}{l}\text { Non-Malignant } \\
\text { (Fibroadenoma) }\end{array}$ \\
\hline & & & $\begin{array}{l}\text { Score III (Central- } \\
\text { Blue, Peripheral- } \\
\text { Green) }\end{array}$ & 2 & Malignant Tumor \\
\hline \multirow{3}{*}{$\begin{array}{l}\text { Hypoechoic lesion having ill-defined/ } \\
\text { irregular margin with or without } \\
\text { posterior attenuation, Transverse } \\
\text { Diameter < AP Diameter }\end{array}$} & \multirow{3}{*}{8} & \multirow{2}{*}{$\begin{array}{c}\text { Increased flow \& PSV } \\
>40 \mathrm{~cm} / \mathrm{sec}\end{array}$} & $\begin{array}{c}\text { Score IV } \\
\text { (Lesion- Blue) }\end{array}$ & 6 & Malignant Tumor \\
\hline & & & $\begin{array}{l}\text { Score V (Lesion + } \\
\text { Surrounding - } \\
\text { Blue) } \\
\end{array}$ & 1 & Malignant Tumor \\
\hline & & $\begin{array}{l}\text { Increased flow But } \\
P S V<40 \mathrm{~cm} / \mathrm{sec}\end{array}$ & $\begin{array}{c}\text { Score IV } \\
\text { (Lesion- Blue) }\end{array}$ & 1 & $\begin{array}{l}\text { Non-Malignant } \\
\text { (Fibroadenoma) }\end{array}$ \\
\hline
\end{tabular}


In our study the Sensitivity, Specificity, Positive Predictive Value (PPV), Negative Predictive Value (NPV) of Sonoelastography in predicting breast malignancy are respectively $87.5 \%, 92.85 \%, 70 \%$ and $97.5 \%$.

\begin{tabular}{|c|c|}
\hline \multicolumn{2}{|c|}{ Screening Test: Sonoelastography } \\
\hline Validity & Value \\
\hline Sensitivity & $87.5 \%$ \\
\hline Specificity & $92.85 \%$ \\
\hline PPV & $70 \%$ \\
\hline NPV & $97.5 \%$ \\
\hline $\begin{array}{c}\text { Table 2: The statistical values of sonoelastography in } \\
\text { predicting malignancy among breast lesions in our study }\end{array}$ \\
\hline
\end{tabular}

\section{DISCUSSION}

We found 20\% malignant lesions, which is quite high from other standard report from West Bengal because our study population was taken from a part of remote area of West Bengal, which differ from the previous study. ${ }^{11}$

Study reveals Blue-Green-Red mosaic pattern on sonoelastography indicate non-malignant cystic lesions.

As per our study SE Score IV, V almost always, but not exclusively indicate underlying malignant lesion. Gheonea IA et al. also found the same findings in their study "Differential diagnosis of breast lesions using ultrasound elastography."12

The Sensitivity and Specificity data in our study are very similar to a study by Aly AM et al. in detecting breast malignancy. ${ }^{13}$ The PPV in this study is $70 \%$, but in other research articles it is around $90 \% .14,15$ The NPV of SE in our study is comparatively similar to many other papers on SE.14,15 On the other hand SE is of limited usefulness in very dense fibrous parenchyma, breast hematoma and breast implants. Some studies have also demolished the value of elastography in the benign and malignant differentiation of lymph nodes.

\section{CONCLUSION}

In conclusion, breast $\mathrm{SE}$ is a very simple and rapid method that can improve the sensitivity and specificity of USG. USG combined with SE is a rapid technique with the lowest costefficiency ratio. It is the most non-invasive and accessible imaging method with high accuracy. Elastography could save thousands of women from the waiting, cost, discomfort and anxiety of a biopsy.

\section{BIBLIOGRAPHY}

1. Sundaravinayagam $\mathrm{S}$, et al. Detection and classification of masses in mammograms using a hybrid GA-PSO-KNN approach. IJARTET 2015;2(5):36-40.

2. National cancer registry programme, Indian council of Medical Research. [Last accessed on 2015 Nov 24]. Available

from:http://www.icmr.nic.in/ncrp/ncrp_p/cancer_reg.pdf
3. Nandkumar A, Gupta PC, Gangadharan P, et al. Geographic pathology revisited: Development of an atlas of cancer in India. Int J Cancer 2005;116:740-54.

4. Heinig J, Witteler $\mathrm{R}$, Schmitz $\mathrm{R}$, et al. Accuracy of classification of breast ultrasound findings based on criteria used for BI-RADS. Ultrasound in Obstetrics and Gynecology 2008;32:573-8.

5. Gokhale S. Ultrasound characterization of breast masses. Indian Journal of Radiology and Imaging. 2009 Aug; 19(3):242-247.

6. Gheonea IA, Stoica Z, Bondari S. Differential diagnosis of breast lesions using ultrasound elastography. Indian Journal of Radiology and Imaging. 2011;21(4):301-305.

7. Itoh A, Ueno E, Tohno E, et al. Breast disease: Clinical application of US elastography for diagnosis. Radiology 2006;239:341-350.

8. Hall TJ, Zhu Y, Spalding CS. In vivo real-time freehand palpation imaging. Ultrasound in Medicine and Biology 2003;29:427-435.

9. Burnside ES, Hall TJ, Sommer AM, et al. Differentiating benign from malignant solid breast masses with US strain imaging. Radiology 2007;245:401-410.

10. Tardivon A. Real-time elasticity findings improve breast specificity: Page 2 of 3 . Diagnostic Imaging. Last update 1st January 2009. Accessed on 8th December 2015. Source: http://www.diagnosticimaging.com/elastography/realtime-elasticity-findings-improve-breastspecificity/page/0/2.

11. Ghosh N, Bandopadhyay R, Tirkey L, et al. Trend and pattern of various types of cancer with special reference to gall bladder cancer in North Bengal Medical College, West Bengal, India: A 3 year's record based study. International Journal of Preventive Medicine. 2015;6:24. doi:10.4103/2008-7802.153860.

12. Gheonea IA, Stoica Z, Bondari S. Differential diagnosis of breast lesions using ultrasound elastography. The Indian Journal of Radiology and Imaging. 2011;21(4):301-305.

13. Aly AM, Helal MH, Shabana AM. Role of sonoelastography in the differentiation between benign and malignant breast lesions. Journal of the Egyptian National Cancer Institute. 2012;22(2):135-142.

14. Evans A, Whelehan P, Thomson K, et al. Quantitative shear wave ultrasound elastography: initial experience in solid breast masses. Breast Cancer Research 2010, 12:R104. Source: http://breast-cancer-research.com/content/12/6/R104.

15. Mousa AE, Aboelatta M, Zalata K. Combined sonoelastographic scoring and strain ratio in evaluation of breast masses. Egyptian Society of Radiology and Nuclear Medicine. 2012;43(4):647-656. 